\title{
Large urethral meatal stone: rare cause of acute urinary retention managed with meatotomy and stone retrieval
}

\author{
Kalpesh Mahesh Parmar, ${ }^{\oplus}$ Saket Singh, Shrawan Kumar Singh, Anuj Sharma
}

Urology, Post Graduate Institute of Medical Education and Research, Chandigarh, India

\section{Correspondence to} Dr Kalpesh Mahesh Parmar, kalpesh010385@gmail.com

Accepted 15 May 2019
Check for updates

(C) BMJ Publishing Group Limited 2019. No commercial re-use. See rights and permissions. Published by BMJ.

To cite: Parmar KM, Singh S, Singh SK, et al. BMJ Case Rep 2019;12:e230731 doi:10.1136/bcr-2019230731

\section{DESCRIPTION}

A 35-year-old man presented with acute-onset urinary retention. The patient had severe pain in the penile region which was partially relieved with analgesics. There was no previous history of flank pain, haematuria or surgery. General physical examination revealed a blackish hard foreign body protruding from the urethral meatus. The adjacent glans and skin appeared normal (figure 1A). A plain radiograph of the pelvis showed a dense radio opaque shadow of around $2 \mathrm{~cm}$ at the level of the urethral meatus (figure 1B). Ultrasound of the abdomen showed the bilateral kidneys were normal with no evidence of hydroureteronephrosis and the urinary bladder was distended. After getting informed consent, dorsal penile block was given and with a ventral meatotomy incision, a large urethral calculus was retrieved using a stone-holding forceps (figure 2A). The meatotomy was closed with chromic catgut 5-0 sutures (figure $2 \mathrm{~B}$ ). The patient voided with immense relief and the pain subsided. At 2 weeks follow-up, the patient is doing well with no fresh complaints and is voiding well. A retrograde urethrogram was done at 4 weeks which showed a normal calibre urethra with no evidence of stricture or diverticulum. Stone analysis revealed a calcium oxalate stone. Urethral stones account for less than $1 \%$ of urinary calculi. ${ }^{1}$ It is commonly associated with renal stone and is likely due to down migration. The most common location is the prostatic urethra. Bothersome voiding is the usual presentation. Urinary retention secondary to urethral meatal stone is extremely rare. Meatotomy under the penile block is reasonably safe and provides prompt relief from symptoms and stone retrieval.

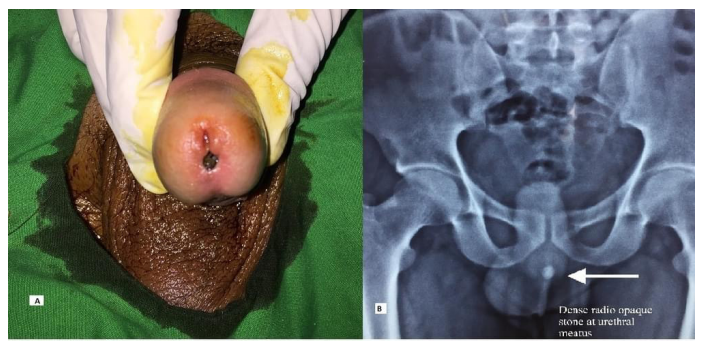

Figure 1 (A) Local examination of penis showing black hard foreign body seen in the urethral meatus.(B) X-ray pelvis showing dense radio opaque shadow present along the course of the penis at the most distal limit.

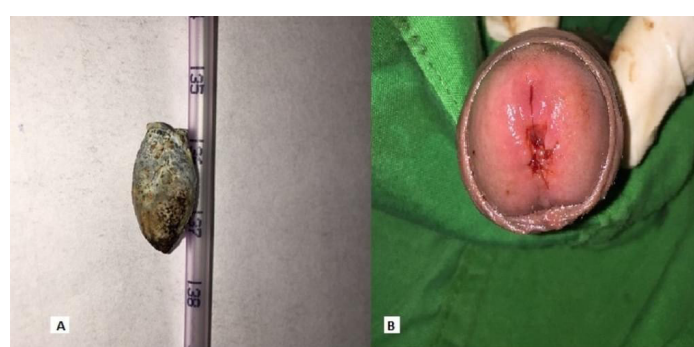

Figure 2 (A) Stone retrieved from urethral meatus measuring $2 \times 1 \mathrm{~cm}$. (B) Meatotomy closure with chromic catgut $5-0$ suture.

\section{Patient's perspective}

I am extremely fortunate and thankful to the whole team of doctors who managed my case so well and relieved my agony.

\section{Learning points}

Large urethral meatus stone in the absence of renal stones is rare.

- Most commonly it is the migration of a renal stone into the lower urinary tract.

- Bothersome unrelenting symptoms are quite distinctive of the obstructing stone in the lower urinary tract.

- Prompt investigation like plain radiograph of the pelvis can diagnose the stone with certainty.

- A simple procedure like meatotomy under local anaesthesia is very effective for stone retrieval.

Acknowledgements The authors thank the patient for being cooperative during the hospital stay.

Contributors KMP and SS collected data and wrote the initial draft. AS edited the images. SKS critically analysed.

Funding The authors have not declared a specific grant for this research from any funding agency in the public, commercial or not-for-profit sectors.

Competing interests None declared.

Patient consent for publication Obtained.

Provenance and peer review Not commissioned; externally peer reviewed.

\section{REFERENCE}

1 Kaczmarek K, Gołąb A, Soczawa M, et al. Urethral stone of unexpected size: case report and short literature review. Open Med 2016;11:7-10. 
Images in...

Copyright 2019 BMJ Publishing Group. All rights reserved. For permission to reuse any of this content visit https://www.bmj.com/company/products-services/rights-and-licensing/permissions/

BMJ Case Report Fellows may re-use this article for personal use and teaching without any further permission.

Become a Fellow of BMJ Case Reports today and you can:

- Submit as many cases as you like

- Enjoy fast sympathetic peer review and rapid publication of accepted articles

Access all the published articles

Re-use any of the published material for personal use and teaching without further permission

Customer Service

If you have any further queries about your subscription, please contact our customer services team on +44 (0) 2071111105 or via email at support@bmj.com.

Visit casereports.bmj.com for more articles like this and to become a Fellow 